\title{
Assessing The Impacts Of COVID 19 On Livestock Production, Market Value Chain And Health Practices In Selected Districts Of East Wollega Zone, Ethiopia
}

Geremew Haile Lemu ( $\nabla$ geremew.wollegauniversity@gmail.com )

Wollega University https://orcid.org/0000-0002-1999-1444

Eyob Hirpa

Wollega University

Morka Amante

Wollega University

Lema Yimer

Wollega University

Walkite Furgasa

Wollega University

Namommsa Anbase

Wollega University

\section{Research Article}

Keywords: Keywords: Animal health, COVID 19, East Wollega, impact, livestock, value chain

Posted Date: June 25th, 2021

DOl: https://doi.org/10.21203/rs.3.rs-612397/v2

License: (c) This work is licensed under a Creative Commons Attribution 4.0 International License.

Read Full License 


\section{Abstract}

COVID-19, caused by a newly discovered strain of coronavirus (SARS-CoV-2), has had a significant impact on many sectors at the global, regional, and national levels, including the livestock sector. Study Methods: A questionnaire survey and observational study were carried out from September 2020 to November 2020 with the aim of assessing the impacts of COVID 19 on livestock farming practices, market chain, consumption of animal products, and animal health care services in selected districts of East Wollega zone. Small scale farmers, abattoir workers, consumers, and private sectors involved in the production, processing, and distribution of livestock products, and veterinarians were purposively selected for this study. Based on the survey, 365 (91.25\%) respondents agreed as the pandemic was the major challenge to livestock farming practices. The assessment shows that COVID 19 created worst 270 (67.5\%) and high impact 75 (18.75\%). The major reasons mentioned were measures taken by the government such as lockdown, economic decline, low number of manpower due to calls to stay at home, and social distance. Observational studies indicated that dairy shops, meat shops, and local abattoirs, hotels, and restaurants were totally/partially closed, especially during the first 6 months of the pandemic. The average monthly income from livestock and their products showed about $60.93 \%$ shortfalls (from $1,130,500$ birr to 688,800 birr). Regarding consumer perception, there was low demand for livestock products mainly due to the perceived disease risk. The most important animal health constraints during this pandemic were unusual preventive practices such as lack of vaccination and deworming, scarcity of drugs at the veterinary clinic, low number of veterinarians and inability to cover the cost of drugs and personnel. The present study suggests that the pandemic's impact on the livestock production, product supply chain and animal health services might be continue, which will have a significant effect on the sustainability of livestock production systems and the contribution of livestock subsectors on the household and national economy and global food security. It is therefore, essential that the government and other concerned bodies should give attention to the livestock sector to mitigate the impacts of the disease.

\section{Introduction}

Ethiopia, with its extensive climate and topography, has one of the world's largest livestock populations [1]. The livestock sector is being increasingly organized into long market chains that employ at least a billion people and directly support the livelihoods of 600 million poor smallholder farmers in developing countries $[2,3]$. The livestock sector is very crucial to provide food to the local market and serve as a source of raw materials, cash income, and foreign currency earnings $[4,5,6,7,8]$. The full range of activities needed to get livestock products such as milk, meat, and eggs to the final consumer through the various stages of production, manufacturing, distribution, wholesaling/retailing, and final consumption are referred to as livestock value chains [9].

The novel coronavirus (COVID-19) epidemic is thought to have started in Wuhan, and it has rapidly spread to almost every country in the world, including Ethiopia [10]. The pandemic is a worldwide problem that necessitates intensive efforts from governments, individuals, companies, and other 
stakeholders. COVID-19 has been declared a global emergency by the World Health Organization (WHO) on March 11, 2020, posing a threat to a broad range of sectors, including health, agriculture, manufacturing, services, retail, social, national, and international value chains, and population groups (rural, urban, casual laborers, self-employed, factory, and government workers) [11, 12].

The diversion of financial, labor, and material resources is one of the early actions that the government has taken to limit the potential spread of COVID-19. This, however, could affect the capacity of various actors not to ensure livestock development and food security in Ethiopia. Lessons from past epidemics such as SARS, MERS-Cov, and Ebola indicate that the current occurrence of COVID-19 will have an impact on the livestock sector disrupting value chains and threatening livelihoods. These will have an impact on the contribution of livestock to household food security and pose risks to the national economy. Possible negative impacts of the COVID 19 pandemic on the livestock sector may be due to closure of government and nongovernment sectors, restriction of movement, social distancing, and decline in economic growth which further limits the demand for livestock products [13]. Movement restrictions due to COVID-19 may cause reduction in availability and delay of timely distribution of veterinary inputs such as drugs and feed and shortage of labor for intensive farm activities. The other may be the absence of market or sudden demand drops in consumer countries during this pandemic [14].

The other factor may be due to local demand and the consumption of animal products has critically declined, mainly because of the perception not to consume raw and chilled animal products with the assumption that such foods are the main routes for the transmission of the virus. As a result, consumers in major market destinations have either reduced the amount they buy or completely avoided the consumption of raw animal products. These negatively affect the livelihood of producers, processors, and value chain actors involved in livestock businesses. On the other hand, the COVID may have a tremendous effect on the export of animal and animal products, primarily due to the inability for export to other countries [15].

Supply food of animal origin to the public and increase in rural income and foreign currency earnings of the country through improving the quality and quantity of market-oriented livestock and their items are the main objectives of the agricultural development policy of Ethiopia [16]. Despite the COVID-19 pandemic has enormous impacts, there is still a lack of scientific documents on the impacts of the disease in the livestock sector in Western Oromia. Therefore, the general objective of this study was to assess the major impacts of the novel corona virus pandemic on livestock production, market value chain and animal health practices in selected districts of East Wollega zone. It is very crucial to quantify the impacts of the pandemic in the livestock sector to design effective strategies for mitigation of the impacts in the sector.

\section{Specific objectives}

- To assess challenges in livestock production during the pandemic in the study area

- To assess the impacts of COVID 19 on livestock market value chains and income 
- To assess the indirect impacts of COVID 19 on animal health care services in the study area

- To assess consumer perceptions towards livestock products

\section{Materials And Methods}

Study Area Description: The study was conducted in four purposively selected districts of East Wollega zone (Nekemte, Sibu Sire, Leka Dulacha, and Jima Arjo districts). East Wollega Zone of Oromia Region is administratively divided in to 21 woredas. The area is agro-ecologically split into $11 \%$ highlands, $49 \%$ midland, and $40 \%$ lowland. The zone has one long rainy season extending from March to mid-October with annual rainfall ranging from $1000-2400 \mathrm{~mm}$. Mixed agriculture (crop and livestock) is the main stay of the farming communities on which their livelihood is fully dependent [17]. East Wollega zone is also acknowledged for its livestock breed known as Horro-breed1 (derives its name from the subprovince of the former Horro Guduru) that has spread widely through Wellega, Illubabor and Keffa and on a small scale to Shewa Zone of the region [18].

Study Design: A cross-sectional study design in the form of a questionnaire survey and observational methods were carried out from September 2020 to November 2020 to collect the data needed for the study. A structured questionnaire was prepared and administered to government, non- governments, and individuals involved in livestock sectors, to assess the major impacts of COVID 19 pandemic on livestock farming practices, marketing system, animal health care practices and human perception towards the consumption of animal products. The questionnaires were framed in such a way that the respondents could give information that are recent and easy to recall and it was filled directly by interviewing purposively selected livestock/farm owners (dairy, beef and poultry farms), abattoir personnel, local consumers, sellers and veterinarians in the selected study areas.

Sample Size Determination: The number of respondents included for purposive sampling was based on the formula recommended by [19].

$\mathrm{N}=0.25 / \mathrm{SE}^{2}$

Where $\mathrm{N}=$ sample size, $\mathrm{SE}=$ standard error assuming the standard error of $5 \%$ at a precision level of 0.05 and the confidence interval of $95 \%$. Accordingly, a total of 400 respondents (100 individuals from each district) were selected and interviewed considering different age, sex, and working conditions.

Data Analysis: Questionnaire data was entered in Microsoft Excels. Data analysis and summarization was made by descriptive by using SPSS Statistical software version 20.

\section{Results}

Livestock Production: The current study found that livestock are a significant aspect of agriculture since they provide traction power, produce items such as milk and milk products, meat, and they are the main source of monetary income (Table 1). 
Table 1: Information on livestock production in the study areas

\begin{tabular}{|c|c|c|c|c|c|}
\hline \multirow{2}{*}{$\begin{array}{l}\text { Knowledge question } n \\
=400\end{array}$} & \multirow[b]{2}{*}{ S/Sire } & \multicolumn{4}{|c|}{ Districts } \\
\hline & & Nekemte & L/Dulecha & $\begin{array}{c}\mathrm{J} / \\
\text { Arjo }\end{array}$ & Total (\%) \\
\hline \multicolumn{6}{|l|}{ Do you keep livestock? } \\
\hline Yes & 80 & 66 & 82 & 79 & $\begin{array}{l}307 \\
(76.75)\end{array}$ \\
\hline No & 20 & 34 & 18 & 21 & $93(23.25)$ \\
\hline \multicolumn{6}{|l|}{ Purpose of keeping livestock } \\
\hline Dairy products & 23 & 27 & 18 & 16 & $84(21)$ \\
\hline Meat & 8 & 12 & 7 & 5 & $32(8)$ \\
\hline Egg & 36 & 45 & 51 & 24 & $156(39)$ \\
\hline Traction power & 52 & 7 & 66 & 49 & $174(43.5)$ \\
\hline Manure & 14 & 8 & 22 & 46 & $90(22.5)$ \\
\hline Cash income & 38 & 46 & 52 & 41 & $\begin{array}{l}177 \\
(44.25)\end{array}$ \\
\hline \multicolumn{6}{|l|}{ Who manages the animals/farm } \\
\hline Husband & 14 & 2 & 32 & 26 & 74 (18.5) \\
\hline Wife & 7 & 9 & 15 & 11 & $42(10.5)$ \\
\hline Children & 16 & 4 & 8 & 6 & $34(8.5)$ \\
\hline Laborers & 5 & 18 & 3 & 6 & $32(8)$ \\
\hline All family & 31 & 9 & 24 & 37 & $\begin{array}{l}101 \\
(25.25)\end{array}$ \\
\hline \multicolumn{6}{|l|}{ Main income } \\
\hline Dairy & 27 & 12 & 18 & 24 & $81(20.25)$ \\
\hline Meat shop & 12 & 26 & 23 & 17 & $78(19.5)$ \\
\hline Poultry & 33 & 29 & 40 & 34 & $136(34)$ \\
\hline Egg & 42 & 50 & 48 & 62 & $202(50.5)$ \\
\hline Beef fattening & 18 & 7 & 11 & 16 & $52(13)$ \\
\hline Government employee & 5 & 9 & 3 & 7 & $24(6)$ \\
\hline
\end{tabular}

Impact of COVID 19 on livestock farming practices: This survey showed that the measures taken by the government such as lockdown, shortage of man power, and decline of income following the COVID-19 outbreak had caused serious problems to livestock farming activities. Calls to stay at home and social distance have affected humanitarian-dependent services in farms, affecting routine work and animal husbandry (low number of laborers, veterinarian visits and services, and workers in product processing) (Table 2).

Table 2: Major impacts of COVID 19 on livestock farming practices in the study area 


\begin{tabular}{|c|c|c|c|c|c|}
\hline \multirow{2}{*}{$\begin{array}{l}\text { Knowledge question } \mathrm{n}= \\
400\end{array}$} & \multirow[b]{2}{*}{$\begin{array}{l}\text { S/ } \\
\text { Sire }\end{array}$} & \multicolumn{2}{|c|}{$\begin{array}{l}\text { Districts } \\
\end{array}$} & \multirow[b]{2}{*}{ J/Arjo } & \multirow[b]{2}{*}{$\begin{array}{l}\text { Total } \\
(\%)\end{array}$} \\
\hline & & Nekemte & L/Dulecha & & \\
\hline \multicolumn{6}{|l|}{$\begin{array}{l}\text { COVID } 19 \text { is the major constraint to } \\
\text { livestock farming }\end{array}$} \\
\hline Yes & 89 & 98 & 82 & 96 & $\begin{array}{c}365 \\
(91.25)\end{array}$ \\
\hline No & 11 & 2 & 18 & 4 & $\begin{array}{c}35 \\
(8.75) \\
\end{array}$ \\
\hline \multicolumn{6}{|c|}{ Measures taken such as lockdown have a negative impact on livestock farming } \\
\hline Yes & 78 & 94 & 83 & 92 & $\begin{array}{c}347 \\
(86.75)\end{array}$ \\
\hline 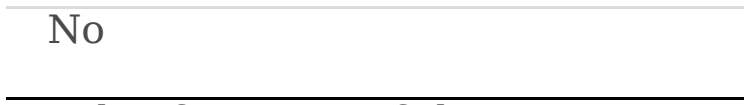 & 22 & 6 & 17 & 8 & $\begin{array}{c}53 \\
(13.25) \\
\end{array}$ \\
\hline \multicolumn{6}{|l|}{ Scale of impacts of the COVID 19} \\
\hline No significant impact & - & 1 & - & 2 & $3(0.75)$ \\
\hline Little impact & 4 & 6 & 2 & 5 & $17(4)$ \\
\hline High impact & 27 & 14 & 16 & 18 & $\begin{array}{c}75 \\
(18.75)\end{array}$ \\
\hline Worst impact & 58 & 77 & 64 & 71 & $\begin{array}{c}270 \\
(67.5)\end{array}$ \\
\hline \multicolumn{6}{|c|}{ There $\quad$ are challenges $\quad$ in animal breeding due to COVID 19} \\
\hline Yes & 85 & 74 & 81 & 72 & $\begin{array}{l}312 \\
(78)\end{array}$ \\
\hline No & 15 & 26 & 19 & 28 & $88(22)$ \\
\hline \multicolumn{6}{|l|}{ If yes what are the main reason/s } \\
\hline Unable to pay for the laborers & 5 & 18 & 3 & 6 & $32(8)$ \\
\hline Unable to purchase vet. drug & 27 & 19 & 31 & 43 & $\begin{array}{l}120 \\
(30)\end{array}$ \\
\hline Activity is not in normal situation, & 65 & 55 & 62 & 58 & $\begin{array}{l}240 \\
(60)\end{array}$ \\
\hline $\begin{array}{l}\text { Low number of laborers } \\
\text { or } \\
\text { Veterinarians }\end{array}$ & 20 & 16 & 13 & 17 & $\begin{array}{c}66 \\
(16.5)\end{array}$ \\
\hline
\end{tabular}

$\mathrm{S} /$ Sire $=$ Sibu Sire L/Dulecha $=$ Leka Dulecha

Impacts of COVID-19 on daily income, marketing chains, and consumer perception: Based on the assessment and observational survey, the marketing chains of livestock and their products are challenged during the COVID- 19 outbreak. The study shows that slaughter houses, meat shops, dairy vendors, and other animal product sellers have been significantly affected. The survey with local distributors and consumers indicated that there was low demand for livestock products such as meat, dairy, and poultry products since the start of the COVID-19 crisis. Important reasons mentioned were the measurements taken to tackle the disease, perceptions of disease risk, and decline in income (Table 3). The daily income from livestock products was declining with prices slightly lowered in retail and local 
markets since the start of the COVID 19 outbreak. The average monthly income from livestock and their products showed about $60.93 \%$ shortfall (from 1,130,500 birr to 688,800 birr) (Figure 1).

Table 3: Major challenges of livestock marketing chains, income, and consumer perception during COVID-19 in the study area

\begin{tabular}{|c|c|c|c|c|c|}
\hline \multirow{2}{*}{$\begin{array}{l}\text { Knowledge question } n= \\
400\end{array}$} & \multicolumn{4}{|c|}{ Positive responses by district } & \multirow[b]{2}{*}{ Total } \\
\hline & S/Sire & Nekemte & L/Dulecha & $\underset{\text { Arjo }}{\mathrm{J} /}$ & \\
\hline \multicolumn{6}{|c|}{ Where do you sell your animals or animal products? } \\
\hline to local market & 48 & 32 & 51 & 64 & $\begin{array}{r}195 \\
(48.75)\end{array}$ \\
\hline to nearby hotels/restaurants & 26 & 38 & 29 & 11 & $104(26)$ \\
\hline to local consumers & 5 & 18 & 2 & 17 & $42(10.5)$ \\
\hline to local butchers & 9 & 8 & 13 & - & $30(7.5)$ \\
\hline to government institution & 2 & 5 & 1 & 3 & $\begin{array}{l}11 \\
(2.75)\end{array}$ \\
\hline
\end{tabular}

Is food of animal origin has been used for consumption as usual?

\begin{tabular}{lccccc} 
Yes & 98 & 100 & 82 & 99 & $\begin{array}{r}379 \\
(94.75)\end{array}$ \\
No & 2 & - & 18 & 1 & $\begin{array}{l}21 \\
(5.25)\end{array}$ \\
\hline
\end{tabular}

Did you face difficulties in selling animals/products in the last 6 months?

\begin{tabular}{lccccc} 
Yes & 87 & 75 & 93 & 81 & $336(84)$ \\
No, & 13 & 25 & 7 & 19 & $64(16)$ \\
\hline
\end{tabular}

There is a change in the price of livestock/products in the last 6 months

$\begin{array}{llllll}\text { Yes } & 92 & 88 & 94 & 91 & 365\end{array}$

\begin{tabular}{lllll} 
No 8 & 12 & 6 & 9 & $\begin{array}{l}(91.25) \\
(8.75)\end{array}$ \\
\hline
\end{tabular}

Scale of daily income change from livestock and their products

\begin{tabular}{lccccc} 
No change & 2 & - & 2 & 1 & $5(1.25)$ \\
Declining & 34 & 18 & 26 & 12 & 90 \\
& & & & & $(22.5)$ \\
Highly declining & 56 & 70 & 66 & 78 & 270 \\
& & & & & $(67.5)$ \\
\hline
\end{tabular}

\begin{tabular}{lccccc}
\hline The most important marketing problems during the pandemic & & & \\
& 72 & 64 & 76 & 63 & 275 \\
Income declining & & & & & $(68.75)$ \\
& 54 & 67 & 41 & 38 & $200(50)$ \\
Restaurant/hotel lockdown & 42 & 75 & 55 & 47 & 219 \\
\hline Lockdown of local distributors & 45 & 58 & 32 & 29 & $164.75)$ \\
\hline Consumer perception & 19 & 12 & 9 & 16 & $56(14)$ \\
\hline Stay home & & & & & \\
\hline
\end{tabular}


Impact of COVID 19 on animal health services: In this study, the indirect impacts of COVID-19 on animal health care practices have been studied. Based on the survey, the most important animal health constraints during this pandemic were unusual preventive practices such as vaccination and deworming, scarcity of drugs at the veterinary clinic, low number of veterinarians, unable to cover the cost of drugs and personnel. The other reasons mentioned were measurements taken such as partial lockdown and physical distancing to combat the pandemic (Table 4).

Table 4: Major impacts of COVID 19 on animal health care services 


\section{Sibu Nekemte L/Dulecha J/Arjo Total Sire}

COVID 19 has an impact on the health of animals

Yes

85

92

86

96

359

No

15

8

14

(89.75)

$4 \quad 41$

$(10.25)$

Do you face challenges to treat sick animals?

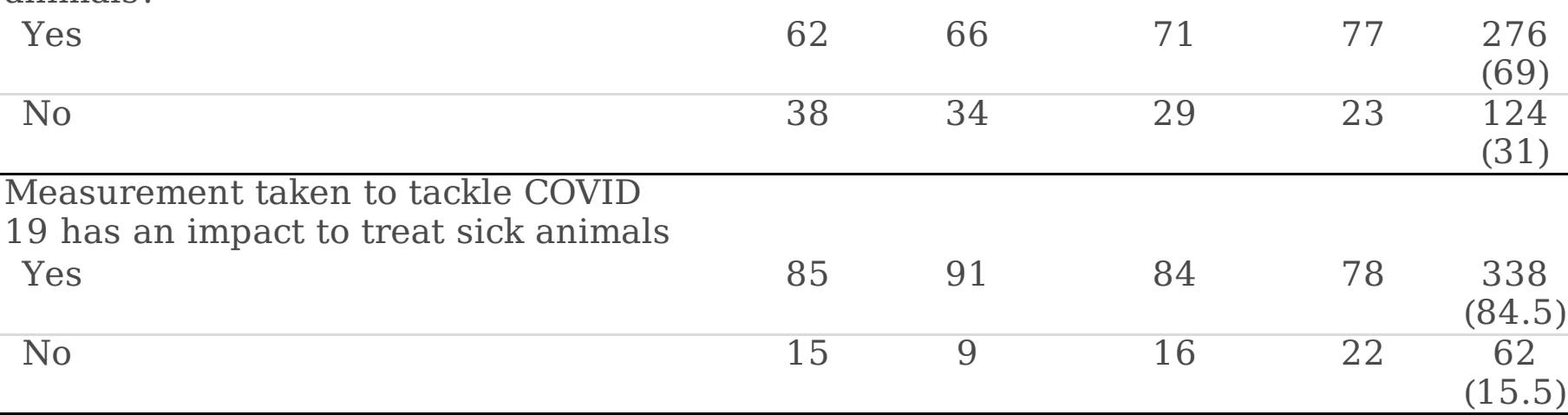

Major animal health

constraints

during the pandemic

$\begin{array}{llllllr}- \text { Scarcity } & \text { of } & \text { veterinary } & 13 & 18 & 7 & 23\end{array}$

drugs

$20 \quad 23$

following lockdown

-Veterinarians not available as usual

20

23

14

16

73

-Preventive

measures

32

21

11

(18.25)

like vaccination are not in practice as

usual

-Unable to buy drugs or pay for vets

22

29

118

82

due to income declined

COVID 19 has impacts on animal disease control/prevention

Yes

78

59

63

68

\section{No}

22

41

37

32

Did you vaccinate or

deworm

animals for the last 6 months

Yes

37

37

41

32

35

145

No

63

59

68

65 (36.25)

Animal health extension service is possible during the pandemic

$\begin{array}{cccccc}\text { Yes } & 26 & 34 & 18 & 39 & 117 \\ \text { No } & & & & & (29.25) \\ & 74 & 66 & 82 & 61 & 283 \\ (70.75)\end{array}$




\section{Discussion}

COVID-19 has had a substantial impact on many sectors at the global, regional, and national levels, including the livestock sector [14]. It is important to recognize the impacts of COVID 19 crisis on the contributions of livestock towards household nutrition, global food security, and economic growth. In the present study, a survey was conducted in four selected districts of East Wollega zone (Sibu Sire, Guto Gida, Leka Dulecha, and Jima Arjo) with the objective of assessing major challenges in animal farming practices, marketing chains, animal health care practices and consumer perception during the COVID 19 pandemic.

In the study area, animal production has been considered as the main component of agricultural development. About 270/400 (67.5\%) of the respondents were keeping livestock for different purposes such as traction power, dairy and poultry products, and manure. Chickens were the main source of income in the study site, followed by dairy, meat selling and beef fattening while a few are government employees. According to this survey, small-scale livestock owners and regular livestock product sellers such as butchers, dairy, and poultry products sellers were one of the major distributors of livestock and livestock products to local consumers, restaurants, hotels and markets.

In the present study, livestock owners, animal farm owners, managers, farm workers, dairy shops, butchers, abattoirs, hotels, and local consumers were interviewed to assess the major impacts of COVID 19 pandemic on livestock farming practices, marketing channel, animal health care practices and consumer perceptions. According to this survey, the pandemic's has created an impact on livestock production and value chain that are critical to deliver economic, social, and nutritional gains in the study areas. Disruptions in the business as a result of the COVID-19 crisis are creating challenges for the distribution of livestock products. The constraints during the COVID-19 outbreak were from the production process to marketing and consumption of animal products. Based on the survey, small-scale farmers, hotels, and private sectors engaged in the production, processing, and distribution of livestock products were critically affected following the pandemic. Observational studies indicated that dairy shops, meat shops, and local abattoirs, which were the major livestock product distributors, were totally closed especially during the first 6 months of the pandemic.

The survey showed that the consumption of livestock products such as meat, dairy, and poultry products in the study area was not as usual since the start of the COVID-19 crisis. Regarding the income, daily income from livestock products was declining with prices slightly lowered in retail and local markets since the start of the COVID 19 outbreak. The primary constraints were the measures taken by the government such as lockdown, shortage of man power, and decline of income. Inability to purchase veterinary inputs due to economic decline, low number of laborers, veterinarians, and other farm workers due to calls to stay at home and social distance has affected the routine farm activities in the study area. The lockdown to tackle the pandemic meant that closure of local markets, hotels, abattoirs, and other 
animal-oriented business that were essential in the distribution of animals /products to consumers, local hotels and markets. The small-scale producers and distributors who rely on animal production for their livelihoods are facing difficulties in selling live animals and products.

Regarding to consumer perception, $164(41 \%)$ of the total respondents in the survey were avoiding the consumption of animal-sourced foods due to the perceived COVID-19 risk. This low demand for livestock products might be linked to Ethiopian media reports at the beginning of the outbreak suggesting that consumption of livestock products such as meat, dairy, and poultry products can result in greater chances of infection. The Ministry of Health has warned the public to avoid consumption of raw foods because of the potential risk of contamination through droplets coming from food handlers. Thus, the perception of risk from livestock products remains particularly meat and dairy products. Similar surveys in Addis Ababa indicated a significant drop in the demand for livestock products such as meat and milk due to consumer fear of disease risk.

Different studies indicated that the COVID-19 pandemic's has had a negative impact on livestock production and supply chain. Many livestock producers and traders have lost their global or local market opportunities, and thus their incomes [14, 20]. Some studies in Ethiopia also indicated COVID-19 has a wide range of impacts on livestock production, consumption of food of animal origin, and value chains $[20,15]$. A qualitative appraisal survey conducted between April 15 and May 10, in Addis Ababa on the dairy value chain supplied showed that commercial and small dairy farmers in urban and rural areas, dairy processors, traders, development agents, urban retailers, and consumers were affected [21]. Previous abattoir survey in Ethiopia indicates that the export abattoirs were facing difficulties to export meat to Middle East [22].

In the present study, the indirect impacts of COVID-19 on animal health care practices have been also studied. Both veterinary professionals and clients were included in the survey. Accordingly, about $89.75 \%$ (365/400) respondents agreed as COVID 19 has an indirect impact on the health of animals. Based on the survey, the most important animal health constraints during this pandemic were unusual preventive practices such as vaccination and deworming, scarcity of drugs at the veterinary clinic, low number of veterinarians, unable to cover the cost of drugs and personnel. The other reasons mentioned were measurements taken such as partial lockdown and physical distancing to combat the pandemic. About 276 (69) respondents were facing difficulties in treating sick animals; while about 255 (63.75) did not vaccinate or deworm their animals during the pandemic. It is suggested that restrictions on human activities affect veterinary services and therefore, affect animal health. This is due to that the COVID-19 outbreak negatively disrupted regular activity. This led to restrictions on the activities of veterinary professionals and insufficient application of daily routine veterinary practices. Such a situation limits a close monitoring of animal requirements and health status and thus impedes the intervention to tackle animal health problems.

\section{Conclusion And Recommendations}


In the present study, survey with the objective of assessing the major impacts of COVID 19 on the livestock subsector was conducted in selected districts of East Wollega zone. The assessment showed that the COVID 19 pandemic has disrupted the livestock production system. The pandemic's has created negative impacts on livestock production and value chains that are critical to deliver economic, social, and nutritional gains in the study areas. Based on the survey, the small-scale farmers and livestock private sector involved in the production, processing, and distribution of livestock products were critically affected following the pandemic. Control measures taken towards pandemic control such as lockdown and stay home, economic decline, and consumer perception were the main reasons mentioned by the respondents. Above all, the pandemic had major animal health constraints with the most important were uncommon preventive practices such as vaccination and deworming, scarcity of drugs at the veterinary clinic, low number of veterinarians, and inability to cover the cost of drugs and personnel. The present study suggests that the pandemic's impact on the livestock production and product supply chain might be continue, which will have a significant effect on the sustainability of livestock production systems and the contribution of livestock subsectors on the household and national economy and global food security.

Based on the above conclusions, the following recommendations were forwarded:

Government and NGO should give strong attention to the livestock sector during the COVID 19 pandemic to alleviate the impacts

Slaughterhouses and private sectors engaged in the production, processing, and distribution of livestock products should be encouraged to be functioning under careful COVID19 prevention measures.

- There should be establishing of COVID 19 teams to monitor livestock-related problems during the pandemic.

Government should arrange especial circumstances to provide veterinary inputs and technical support.

There should be training for consumers regarding the relationship between the COVID 19 virus and livestock products to clear consumer confusion.

Studies to investigate the occurrence of the virus in food of animal origin should be conducted.

\section{Declarations}

\section{Data Availability}

The data used to support the findings of this study will be included if necessary.

\section{Authors' Contributions}

The main author wrote up the literature, supervised the work, analyzed date and wrote up the paper. The Co-authors: wrote up the literature, collected data and edited the paper. 
Conflict of Interest: The authors declare that they have no conflicts of interest.

Acknowledgements: We are very much grateful to Wollega University, Directorate for Research and Technology transfer for funding this thematic research.

\section{References}

1. CSA (2016): Central Statistics Authority, Population Projection of Ethiopia for All Regions.

2. Roger, B., Robert, C., Tom, S. (2003): Pro-Poor Livestock Policy Initiative, a study of the role of livestock in poverty reduction strategy papers. A living from livestock PPLPI working paper no. 1.

3. Thornton P.K., Vande Steeg J., Notenbaert A., Herrero M. (2009): The impacts of climate change on livestock and livestock systems in developing countries: a review of what we know and what we need to know. Agric. Syst. 101, 113-127

4. Belachew, H., Jemberu, E. (2003): Challenges and opportunities of livestock marketing in Ethiopia. In: Proceedings of the 10th annual conference of the Ethiopian Society of Animal Production (ESAP) held in Addis Ababa, Ethiopia, August 21-23, 2002. Addis Ababa, Ethiopia. pp 1-13.

5. Getahun, L. (2008): Productive and Economic performance of Small Ruminant production in production system of the Highlands of Ethiopia. Ph.D dissertation. University of Hohenheim, Stuttgart-Hoheinheim, Germany.

6. Belete, S. (2009): Production and marketing systems of small ruminants in Goma district of Jimma zone, western Ethiopia.

7. Behnke, R. (2010): The Contribution of Livestock to the Economies of IGAD Member States: Study Findings, Application of the Methodology in Ethiopia and Recommendations for Further Work. UK: Odessa Centre, IGAD Livestock Policy Initiative, Great Wolford; IGAD LPI Working Paper 02-10.

8. Dejene, S., Abebe, B., Degefu, H. (2013): Study on the Major Health Problems That Causes Carcass and Organs Condemnation at Hashim\s Export Abattoir, Debrezeit, Ethiopia. Global Vet., 11(4): 362371.

9. ILRI (2011): International Livestock Research Institute. Livestock policy analysis. ILRI Training Manual 2. ILRI, Nairobi, Kenya, Pp. 264.

10. WHO (2020): Coronavirus disease (COVID-19) technical guidance: Laboratory testing for 2019-nCoV in humans. https://www. who.int/emergencies/diseases/novel-coronavirus- 2019/tech nicalguidance/laboratory-guidance.

11. Triggs, A., Kharas, H. (2020): The triple economic shock of COVID-19 and priorities for an emergency $\mathrm{G}-20$ leaders meeting.

12. ILO (2020): International Labour Organization. COVID-19 and world of work: Impacts and responses, Geneva.

13. Degye, G., Tadele, F., Getachew, D., Mengistu, K. (2020): Economic and Welfare Effects of COVID-19 and Responses in Ethiopia: Initial insights, Ethiopian Economic Policy Research Institute (EEPRI. 
14. FAO (2020a): Addressing the impacts of COVID-19 in food crises. Food and Agriculture Organization of the United Nations

15. Forsido, S.F., Mitiku, F., Lemessa, F., Tolemariam, T., Belew, D., Berecha, G., Garedew, W., Bekele, Y., Geda, F., Eneyew, A.. (2020): COVID-19 Probable Impacts on Ethiopian Agriculture and Potential Mitigation and Adaptation Measures: No Food-No Health-No Life. Jimma, Ethiopia: Jimma University, 2020.

16. Mohammed, A., Fatiha, Y. (2019): Production of hide and skin in Ethiopia; marketing opportunities and constraints: A review paper. Cogent food and agriculture, 5 (2019)

17. Dechassa, L. (2003): Surplus producing eastern highland parts of Eastern Wellega zone badly hit by current crisis. Office for the Coordination of Humanitarian Affairs (OCHA) Ethiopia.

18. Bako Agricultural Research Centre annual report (2003): Bako, Oromia, Ethiopia.

19. Arsham, H. (2002): Questionnaire Design and Surveys Sampling, Survey: The Online Survey Tool. Http: //home.ubalt.edu/ntsbarsh/Business-stat. Accessed on 20 September 2014.

20. FAO (2020b): Guidelines to mitigate the impact of the COVID-19 pandemic on livestock production and animal health.

21. Agajie, T., Yetimwork, H., Bart, M. (2020): COVID-19 is shifting consumption and disrupting dairy value chains in Ethiopia JUNE 1, 2020. International Food Policy Research Institute

22. Yared, T. (2020): Covid-19 disrupts crucial meat export sector in Ethiopia.

\section{Figures}

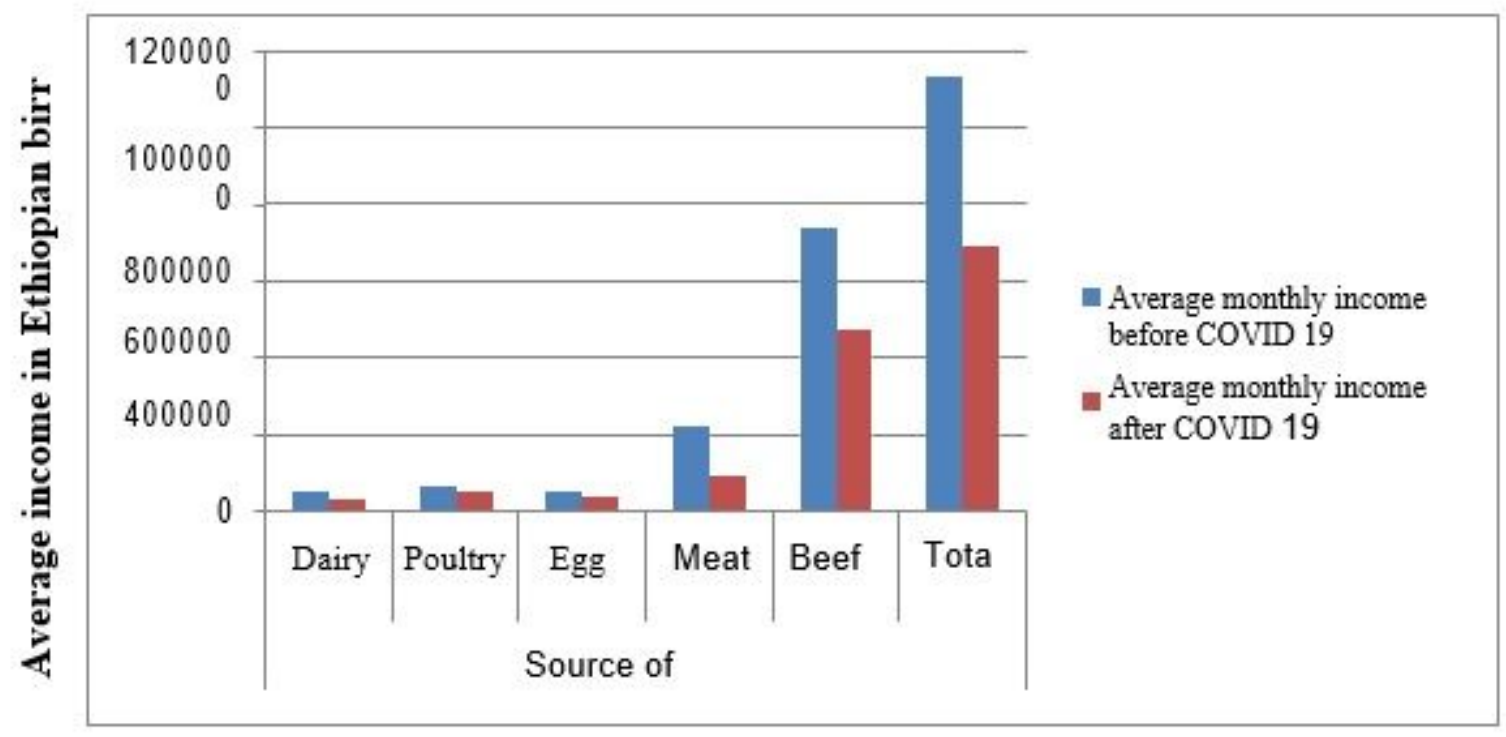

\section{Figure 1}

Average monthly income before and after the occurrence of COVID 19 crisis 